\title{
Measuring customer profitability through time-driven activity- based costing: a case study at hotel $x$ Jogjakarta
}

\author{
Garry Billy Ardiansyah ${ }^{1}$, Bambang Tjahjadi ${ }^{2}$, Noorlailie Soewarno ${ }^{3, *}$ \\ ${ }^{1.2,3}$ Faculty of Economics and Business, Universitas Airlangga, Surabaya-Indonesia
}

\begin{abstract}
Travelling intensity has been higher in the past few years making hospitality industry must be ready to provide the best service at optimum prices to customers who purchase and enjoy the services. Hotel as one of the accommodation service providers should be able to allocate resources accurately according to the actual needed capacity and thorough tariff policy for not losing the competition and obtain profit according to how much is projected. TDABC system is the most updated costing system which can assist the allocation of these resources. TDABC system is considered twice important to be applied in the service industry as service is intangible so costing system must show the exact and accurate number of resources used to provide the service. Through TDABC system, Customer Profitability Analysis is conducted with the aim of knowing the level of profitability every customer type possesses and classifying them as profitable or non-profitable customers. A case study had been conducted in a five-star hotel located in the Special Region of Jogjakarta resulting a profit recognized under TDABC system that traditional method used as the hotel's costing system failed to do so and more proper data on costs and profitability of customers.
\end{abstract}

\section{Introduction}

Travelling has become a contemporary lifestyle adopted by the modern society lately. Indonesia, as the largest archipelago country in the world, saves million choices of tourist destination for local and international tourists. One of the famous tourist destinations in Indonesia is the Special Region of Jogjakarta, better known as Jogjakarta. Jogjakarta wonderfully preserves its local cultural wisdom that is very well guarded under distinctive government system called sultanate or Kasultanan Ngayogyakarta Hadiningrat that is currently under the leadership of Sultan Hamengkubuwono $\mathrm{X}$. The growing potential of tourism in Jogjakarta increases the need of service that can accommodate these people in order to have a pleasant and satisfying experience. The continuing development of the hospitality industry in Jogjakarta absolutely sparks the unavoidable competition between service companies.

[1] One of the challenges in running service businesses is the development of cost information to create strategic decisions and set a proper price of services. The rising competition in hospitality industry has also fuelled the attention jet to introduce a wider range of new product and service aims to solely meet customers' satisfaction. Therefore, knowledge of customer cost information is worth having to understand exactly what customers want and how much the cost necessary to provide such services. Customer cost data assists managers to identify profitability level of customers in order to improve decision making and target profit setting [2]. A company which has valuable information in comprehending and identifying customers who are more profitable or not will help advance the overall organizational profitability [3]. Customer cost information is considered very helpful in maintaining the level of profits and retain customer relationship, especially in hospitality industry. Customer Profitability Analysis is in charge of allocating revenues and costs generated from segmented customers with the help of customer costs information to gain knowledge of customer profitability.

Time-Driven Activity-Based Costing system has been proven to be capable of producing reliable financing system without spending significant time and cost. Hotel provides more than accommodation for customers in the rapidly growing service market so the application of TDABC system can support the analysis of customer profitability. TDABC systems allows hotel to look at what really happens inside by discovering practical capacity of resources supplied using time as the resource driver and points out the unused capacity where management may eliminate directly or seeking out the benefit they can get.

Hotel X is a newly-open 5-star hotel in Special Region of Jogjakarta which considered having the most outstanding performance in 2014. Not only occupying $17.98 \%$ of market and simultaneously beating its 8 competitors, but also achieving Highest Revenue and Highest Average Room Rate (ARR) proved that it could do beyond expectation.

* Corresponding author: noorlailie@gmail.com 
However, hotel seemed to still use traditional method of costing system and had not yet to take a look closely at its customer behavior and profitability. Traditional costing system provided less accurate financial information and customer segmentation was only conducted to see the statistics of its guests and no further than that. Author feels the need to introduce Hotel X Jogjakarta to CPA through TDABC system in order to provide more accurate cost information and customer profitability for managers for future effective and efficient strategies. There are two research questions based on the previous introduction:

1. How to design Time-Driven Activity-Based Costing System (TDABC) to determine customer profitability in Hotel X Jogjakarta?

2. How is the comparison of Customer Profitability Analysis using hotel's existing system and TDABC system?

Expected benefits of this research for Hotel X Jogjakarta is as consideration to use more accurate and efficient costing system, to understand the level of customer profitability based on its customer segmentation, to create more effective future strategy for achieving more profit according to customer behavior, and to decide about what hotel wants towards the unused capacity found during the application of TDABC system so that unnecessary cost can be eliminated. Author can also have the practical knowledge of the theories lectured in Cost Accounting and Management Accounting. This research can be used for academics as a new insight and research material related with Time-Driven ActivityBased Costing and its application in the hospitality industry in Indonesia as well as a reference for further research.

\section{Literature Review}

Cost is the value of resources used to create or obtain something which is a focus in cost accounting [4]. [5] explain that expense is the costs incurred during the process of obtaining revenue in an accounting period, while costs are acquired when resources are used. [6] states that cost accounting is the sum of the total calculated costs assigned to build and control activities, develop quality and efficiency, and support decision-making. Cost Accounting can also be viewed as a combination of financial and management accounting that is made to meet the needs of information by presenting all prominent details about the cost of product or service in which internal party use for planning, control, decision making, and performance evaluation of the company as well for external parties regarding the financial reporting and investment decision making [7]. There are some functions of cost accounting for the company's management mentioned by [8], namely:

1. Create and execute a plan that can motivate employees to work in accordance with the targets set in the company's budget, consistency, and desired economic conditions during the planning process.

2. Design an effective and efficient costing, therefore its quality can be thoroughly controlled and developed.

3. Control the quantity of inventory that company has and provide information regarding the costs assigned to products or services made for pricing determination and performance evaluation.

4. Find out the costs and profit earned during the making of annual financial statements or even in a shorter time depending on how the management desires in accordance with both internal and external reporting rules.

5. Consider the use of short term and long term alternatives that can influence costs and revenues.

[9] introduced Time-Driven Activity-Based Costing (TDABC) system, an upgrade version of Activity-Based Costing system, is simpler, less money-involving and time-consuming yet company will obtain a far more accurate information than the previous $\mathrm{ABC}$ system by eliminating the need to interview and conduct employee surveys that are long and complicated only to seek for information about the allocation of resource costs to activities. They listed down the advantages of TDABC system:

1. Easier and faster to build an accurate models.

2. Integrates well with the data now available from ERP and customer relationship management systems (this makes the system more dynamic and less people-intensive).

3. Driver costs to transactions and orders using specific characteristics of particular orders, processes, suppliers, and customers.

4. Can be run monthly to capture the economics of the most recent operations.

5. Provides visibility to Process Efficiencies and capacity utilization.

6. Forecasts of resource demands, allowing companies to budget for resource capacity on the basis of predicted order quantities and complexity.

7. Is Easily scalable to enterprisewide models via enterprise-scalable software applications and database technologies.

8. Enables fast and inexpensive maintenance models.

9. Supplies granular information to assist users with identifying the root cause of problems.

10. Can be used in any industry or company with complexity in customers, products, channels, segments, and processes and large amounts of people and capital expenditures.

Customer cost information is a substantial key managerial decision making [10]. Knowing the amount of actual costs in providing services to customers is no doubt important in all companies by means to know the actual profit earned. Customer Profitability Analysis (CPA) works by allocating all revenues and costs to particular customers with the aim to calculate each individual's profitability level. However, [11] pointed out the need of appropriate costing 
systems and precise cost techniques if the company wants to obtain accurate information regarding its activities and customers in purpose of conducting CPA. Not only TDABC system has proved sufficient and capable of supporting the need of accurate data, it also has extensive influence such as negotiations with business partners to achieve win-win solutions among the supply chain members. An effective use of CPA obviously helps service companies to be better in increasing both customer satisfaction and profitability [12].

[13-15] had also studied the application of TDABC in service industries, although none of them made customers as their unit of study and conducted the study in Special Region of Jogjakarta. The result shows significant difference between the cost under the existing organizations and under TDABC system, so does the result of this research. Conceptual framework that underlines this research begins with gathering a collection of revenue, cost, and customer segmentation report. Those data were processed to allocate the revenue and cost to customer groups under hotel's costing system and TDABC system. The result which came up under both systems was made a comparison of customer profitability using the CPA program.

\section{Research Method}

In accordance to the research objectives, this study possesses a qualitative approach using case study method. [16] stated that qualitative approach concentrates more on the process rather than the result and not aim for data or evidence as proof of whether research hypothesis is right or wrong.[17] also argues that qualitative descriptive approach turns out to be commonly used in research that features case study which focuses on the characteristics of a particular unit among various phenomenon. [18] argues that findings and conclusions obtained from a case study based on several sources of information would be more convincing and correct.

This research was conducted at Hotel X Jogjakarta in order to determine the level of customer profitability. All data owned by hotel of revenues and costs from its main activities during 2014 is allocated based on its consumer segmentation. The data obtained is processed and analysed in accordance with the qualitative approach as following:

1. Figuring out what data is needed to create the Customer Profitability Analysis using TDABC system of the activities of the hotel.

2. Collecting the data by field observation, documentation, and interview with manager and key person of each related department.

3. Processing the data which has been collected into TDABC system.

4. Analysing customer profitability from the calculation results using CPA.

5. Comparing customer costs and profitability according to the existing system and TDABC system.

\section{Results and Discussion}

\subsection{Customer Segmentation}

I. TRANSIENT : individual booking or less than 10-person booking in published rate who check in directly to reception desk with special rate from DOR or DOSM, booking in promotional or seasonal rate, corporate or government representatives, booking from travel agent or online travel agent, individual advance purchase (room voucher gift), owners of the hotel, individual who applies special rate approved by DOSM or GM, and barter.

II. GROUP : Group booking consists of 10 or more persons from corporate or government representatives, from travel agent, from commercial and social associations, and social groups.

III. CONTRACT : individual or group booking for fourteen consecutive nights and Airlines Contract Rate (crew and non-crew of Airlines Company).

IV. WALK-IN : individual or group coming to hotel only to enjoy having meals at restaurant.

\subsection{Revenue Allocation to Customer Groups}

Main revenue of Hotel X Yogyakarta is derived from sales of rooms and food and beverages. In details of room revenue, revenue has been classified according to the segmented customers every month. Total customer who stayed at the hotel in 2014 is obtained by multiplying the total of rooms sold in 2014 (59.068 rooms) with room : customer ratio of 1.8 suggested by Director of Sales and Marketing, reaching a total of 105.188 customers during 2014.

Food and beverages revenue is still based on cover; manager assumption is used to allocate food and beverages revenue of Hotel X Jogjakarta in 2014 to customer groups. Total customer of breakfast is grouped by the total in-house guests in 2014 and the difference between the total in-house guests with total breakfast customers goes into group IV. Total customer of lunch and dinner is grouped using the percentage of $10 \%$ group I, $80 \%$ group II, $0,5 \%$ group III, and 9,5\% group IV. Group I managed to earn Rp45.229.171.806 in total, group II earned Rp24.521.710.163 in total, group III earned Rp183.426.176 in total, and group IV earned Rp970.431.664 in total. 


\subsection{Cost Allocation to Customer Groups under Hotel's Costing System}

Because the operating costs has not been allocated yet to customer groups by Hotel X Jogjakarta, author assumed that the cost allocation is based on the percentage of revenue that every customer group possesses assuming that a group who generates higher total revenue also gathers higher total cost. Total cost of group I is Rp43.172.937.034, total cost of group II is Rp24.382.158.361. total cost of group III is Rp172.247.356, and total cost of group IV is Rp1.317.086.628 under hotel's costing system.

\subsection{Cost Allocation to Customer Groups under TDABC System 4.4.1 Activities Performed in Hotel \\ Front Office \\ Food and Beverages \\ Housekeeping Marketing \\ : Welcoming customers, check-in process, escorting guests in, billing review, closing bill, and escorting guest out.}

\subsubsection{Cost of Capacity Supplied to Main Activities}

In the consolidated profit and loss report of Hotel X Jogjakarta in 2014, all costs had not been allocated yet to main activities. Therefore, it is a prominent process to attribute these facility-sustaining costs fairly one by one to the activity centres first than to be traced directly to individual customer. Since this type of costs cannot be determined as specific costs for particular customers, they are first apportioned to the activity-cost pools. Total cost of capacity supplied to front office activities is Rp7.086.785.409, to food and beverages activities is Rp14.054.764.886, to housekeeping activities is Rp30.296.098.999, and to marketing activities is Rp8.148.877.980.

\subsubsection{Allocation of Costs of Front Office Activities to Customer Groups}

Costs of front office include direct and indirect costs such as rooms, utilities, depreciation, etc. The costs pooled in front office activities were allocated to customer groups based on the practical capacity of receptionists. The time equation represents the estimate time required for front office activity:

Front office activity $=\left(8,5^{*}\right.$ \#customers $)\left[\right.$ if customer group 1] $+\left(8^{*}\right.$ \#customers $)[$ if customer group 2] + $\left(13^{*} \#\right.$ customers $)[$ if customer group 3$]+(2 * \#$ customers $)[$ if customer group 4$]$

Hotel employs 10 receptionists to perform front office activities in 2014. All receptionists are fixed employee. The theoretical working time for one fixed employee corresponds to total of 146.400 minutes per year ( 8 hours x 60 minutes/hour x 305 days/year). However, every day one fixed employee gets one hour to rest and 12 days of paid leave every year so, the practical working time is 123.060 minutes ( 7 hours x 60 minutes/hour x 293 days/year). Total practical working time of 10 receptionists is 1.230 .600 . To assign cost according to TDABC, time equation is multiplied with capacity cost rate (Rp7.086.785.409/1.230.600) which is Rp5.759. Total cost of front office activities amounted Rp3.286.065.244 is allocated to group I, Rp1.738.296.560 is allocated to group II, Rp24.631.243 is allocated to group III, and Rp106.011.672 is allocated to group IV. Around 73\% of allocated cost had actually been used for productive work in 2014 so unused capacity of front office activities is around $27 \%$ of allocated cost.

\subsubsection{Allocation of Costs of Food and Beverages Activities to Customer Groups}

Costs of food and beverages include direct and indirect costs such as food and beverages, depreciation, etc. The costs pooled in food and beverages activities were allocated to customer groups based on the practical capacity of related personnel. The time equation represents the estimate time required for front office activity is developed per meal cover. Buffet was only served once per cover so there was no need to multiply it with the number of customers.

Breakfast $=30+(32 * \#$ customers $)[$ if customer group 1$]+(32 * \#$ customers $)[$ if customer group 2$]+(32 * \#$ customers $)[$ if customer group 3$]+(32 * \#$ customers $)[$ if customer group 4$]$

Lunch $=60+\left(48^{*} \#\right.$ customers $)\left[\right.$ if customer group 1] $+\left(48^{*} \#\right.$ customers $)\left[\right.$ if customer group 2] $+\left(48^{*} \#\right.$ customers $)[$ if customer group 3] + (48*\#customers) [if customer group 4]

Dinner $=60+\left(48^{*} \#\right.$ customers $)\left[\right.$ if customer group 1] $+\left(48^{*} \#\right.$ customers $)\left[\right.$ if customer group 2] $+\left(48^{*} \#\right.$ customers $)[$ if customer group 3] + (48*\#customers) [if customer group 4]

Buffet prep. $=30$ (breakfast buffet) +60 (lunch buffet $)+60$ (dinner buffet)

Hotel employs 17 fixed personnel and 80 waitress trainees to perform food and beverages activities in 2014 . Trainees only worked for 6 months with 30 days off in total and 4 hours/day so their practical working time is 2.937 .600 minutes ( 80 trainees x 153 days x 4 hours x 6 minutes/hours). Fixed personnel are fixed employee which practical working time has been calculated before so the total practical working time in food and beverages activities is 5.029.620 minutes [(17 fixed employee $\mathrm{x} 123.060)+2.937 .600]$. To assign cost according to TDABC, time equation is multiplied with capacity cost rate (Rp14.054.764.886/ 5.029.620) which is Rp2.794. Total cost of food and beverages activities amounted Rp8.705.747.074 is allocated to group I, Rp8.057.556.213 is allocated to group II, Rp61.904.582 is allocated to group III, and Rp1.242.844.489 is allocated to group IV. Around 95\% of allocated cost had actually been used for productive work in 2014 so unused capacity of food and beverages activities is around $5 \%$ of allocated cost. 


\subsubsection{Allocation of Costs of Housekeeping Activities to Customer Groups}

Costs of housekeeping include direct and indirect costs such as rooms, food and beverages, depreciation, etc. The costs pooled in housekeeping activities were allocated to customer groups based on the practical capacity of housekeepers. The time equation represents the estimate time required for housekeeping activity:

Housekeeping activity $=\left(43^{*}\right.$ \#customers $)\left[\right.$ if customer group 1] $+\left(57^{*}\right.$ \#customers $)[$ if customer group 2] + (43*\#customers) [if customer group 3]

Hotel employs 12 housekeepers, 8 six-month contract housekeeper, and 80 housekeeper trainee to perform front office activities in 2014. The theoretical working time for one six-month contract employee corresponds to total of 73.440 minutes per year ( 8 hours x 60 minutes/hour x 153 days/year). However, every day a six-month contract employee gets one hour to rest and 6 days of paid leave so the practical working time is 61.740 minutes ( 7 hours $\mathrm{x}$ 60minutes/hour x 147 days/year). Total practical working time of housekeeping activities is 4.908 .240 minutes [(12 x $123.060)+(8 \times 61.740)+(80 \times 36.720)]$. To assign cost according to TDABC, time equation is multiplied with capacity cost rate (Rp30.296.098.999 / 4.908.240) which is Rp6.172. Total cost of housekeeping activities amounted Rp16.572.807.520 is allocated to group I, Rp12.109.217.120 is allocated to group II, and Rp81.223.520 is allocated to group III. Around $95 \%$ of allocated cost had actually been used for productive work in 2014 so unused capacity of housekeeping activities is around $5 \%$ of allocated cost.

\subsubsection{Allocation of Costs of Marketing Activities to Customer Groups}

Costs of marketing activities include direct and indirect costs such as rooms, depreciation, property insurance, etc. The costs pooled in marketing activities were allocated to customer groups based on the practical capacity of associates. The time equation represents the estimate time required for marketing activity:

Marketing activity $=\left(45^{*}\right.$ \#visits $)\left[\right.$ if customer group 1] $+\left(105^{*} \#\right.$ visits $)[$ if customer group 2$]+\left(45^{*} \#\right.$ visits $)[$ if customer group 3]

Hotel employs 5 associates to perform marketing activities in 2014. All associates are fixed employee so the total practical working time is 615.300 minutes $(5 \times$ 123.060). To assign cost according to TDABC, time equation is multiplied with capacity cost rate (Rp8.148.877.980 / 615.300) which is Rp13.244. Total cost of marketing activities amounted Rp6.277.353.266 is allocated to group I, Rp4.151.615.236 is allocated to group II, Rp106.668.493 is allocated to group III, and Rp383.144.130 is allocated to group IV. Around 76\% of allocated cost had actually been used for productive work in 2014 so unused capacity of marketing activities is around $24 \%$ of allocated cost.

\subsection{Customer Profitability Analysis}

To calculate the profitability of every customer group, the assigned revenue of customer groups is reduced with the assigned costs under both hotel's costing system and TDABC system. As can be seen in the following table, only group I managed to generate profit for Hotel X Jogjakarta under TDABC system and all these groups are losable ones under hotel's costing system. In overall however, TDABC system recognized profit of almost three billion rupiahs where hotel's costing system failed to do so.

Table 1. Customer Profitability Analysis in 2014 under Hotel's Costing System and TDABC System

\begin{tabular}{|c|c|c|c|c|c|c|c|c|}
\hline $\begin{array}{c}\text { Grou } \\
\mathbf{p}\end{array}$ & $\begin{array}{l}\text { Revenue } \\
\text { (a) }\end{array}$ & $\begin{array}{l}\text { Hotel's Costing } \\
\text { System } \\
\text { (b) } \\
\end{array}$ & $\begin{array}{l}\text { Profit } / \text { Loss } \\
\quad(c=a-b)\end{array}$ & $\begin{array}{c}\begin{array}{c}\text { Profita } \\
\text { bility } \\
\text { (c/a) }\end{array} \\
\end{array}$ & $\begin{array}{c}\text { TDABC } \\
\text { System } \\
\text { (d) } \\
\end{array}$ & $\begin{array}{l}\text { Profit / Loss } \\
\quad(e=\text { a-d })\end{array}$ & $\begin{array}{c}\text { Profita } \\
\text { bility } \\
\text { (e/a) }\end{array}$ & $\begin{array}{c}\text { Deviation } \\
\text { (f }=\mathbf{b}-\mathbf{d})\end{array}$ \\
\hline I & 41.279 .484 .940 & 43.172 .937 .034 & $(1.893 .452 .094)$ & $-4,6 \%$ & 34.841 .973 .103 & 6.437 .511 .837 & $17,0 \%$ & 8.330 .963 .931 \\
\hline II & 22.301 .790 .579 & 24.382 .158 .361 & $(2.080 .367 .782)$ & $-9,3 \%$ & 26.056 .685 .128 & $(3.754 .894 .549)$ & $-15,0 \%$ & $\begin{array}{c}(1.674 .526 .767 \\
)\end{array}$ \\
\hline III & 164.240 .922 & 172.247 .356 & $(8.006 .434)$ & $-4,9 \%$ & 274.427 .838 & (110.186.916) & $-65,4 \%$ & $(102.180 .482)$ \\
\hline IV & 970.431 .664 & 1.317 .086 .628 & (346.654.964) & $-35,7 \%$ & 1.732 .000 .292 & (761.568.628) & $-78,5 \%$ & (414.913.664) \\
\hline \multicolumn{5}{|c|}{ Unused Capacity } & 6.139 .343 .018 & & & \\
\hline Total & $\begin{array}{c}\text { Rp64.715.948.1 } \\
05\end{array}$ & $\begin{array}{c}\text { Rp69.044.429.3 } \\
79\end{array}$ & $\begin{array}{c}\text { (Rp4.328.481.27 } \\
4)\end{array}$ & $-6,7 \%$ & $\begin{array}{c}\text { Rp69.044.429.3 } \\
79\end{array}$ & $\begin{array}{c}\text { (Rp4.328.481.27 } \\
4)\end{array}$ & $-6,7$ & $\begin{array}{c}\text { Rp6.139.511.8 } \\
37\end{array}$ \\
\hline
\end{tabular}

\section{Conclusions and Suggestions}

It can be concluded that:

(1) Hotel X Jogjakarta still uses traditional system as its costing system which resulted in an inaccurate cost of customers and their profitability level. The conduct of CPA showed loss generated from all customer groups but only group I who were the profitable one and the remaining groups actually consumed resources more than hotel's costing system could realize.

(2) TDABC system application had been proven to be more accurate since its result of a higher profitability and information of unused capacity in every main activity. 
(3) Information retrieved from CPA can be used as consideration in future pricing policy and strategy making decision to distinguish profitable customers from non-profitable ones.

(4) Author suggests data of revenues, direct cost, and total quantity of every activity have been allocated in group by the company according to its customer segmentation for further research.

\section{References}

1. A.Terungwa. Int. Jr. Fin. Acct. 2, 6 (2013)

2. D. Kuchta, M. Troska. Jr. Cst. Mgt 23, 4 (2007)

3. E.M. Van Raaij. Mkt. Int. \& Plg. 23, 4 (2005)

4. W.N.Lanen. Fundamentals of Cost Accounting (McGraw-Hill Education, 2010)

5. D.R. Hansen. Cornerstones of Managerial Accounting (Cengage Learning, 2013)

6. W. K. Carter, M.E. Usry. Cost Accounting (Salemba Empat, 2009)

7. C.A. Raiborn, M.R. Kinney. Cost Accounting Principles (South-Western: Cengage Learning, 2013)

8. W.K. Carter. Cost Accounting. (Mason: Thomson, 2006)

9. R.S. Kaplan, S.R. Anderson. Time-Driven Activity-Based Costing: A Simpler and More Powerful Path To Higher Profit (Harvard Business School Publishing Corporation, 2007)

10. I. Dalci, T. Tanis, L. Kosan. Int. Jour. of Cont. Hosp. Mgt. 22, 5 (2010)

11. O. Dejnega. Journal of Applied Economic Sciences, 1,15 (2011)

12. B.Cotton. Ch. Acct. Jour. 84, 3 (2005)

13. S.R. Dewanta. The Application of Time-Driven Activity-Based Costing (TDABC) in Determining Cost Per Room and Efficiency Level of Costs and Resources: Case Study in Hotel Y Surabaya (FEB Universitas Airlangga, 2015)

14. F.H. Fahrizal. Analisis Penerapan Time-Driven Activity-Based Costing Dalam Perhitungan Harga Pokok Produksi Pada Perusahaan Biro Wisata Umrah PT. Mina Wisata Islami (FEB Universitas Airlangga, 2015)

15. M.D. Riediansyaf. Designing Time-Driven Activity-Based Costing (TDABC) In Room Division at Hotel X Malang (FEB Universitas Airlangga, 2013)

16. S. Wahyuni. Qualitative Researh Method Theory and Practice (Jakarta: Salemba Empat, 2012)

17. B. Bungin. Penelitian Kualitatif: Komunikasi, Ekonomi, Kebijakan Publik, dan Ilmu Sosial Lainnya (Jakarta: Kencana Prenada Media Group, 2008)

18. R.K. Yin. Case Study Research: Design and Method (California: Sage Publication, 2003) 